\title{
Maximal exercise test is a useful method for physical capacity and oxygen consumption determination in streptozotocin-diabetic rats Bruno Rodrigues ${ }^{1}$, Diego M Figueroa ${ }^{2}$, Cristiano T Mostarda1, Marcelo V Heeren ${ }^{2}$, Maria-Cláudia Irigoyen ${ }^{1}$ and Kátia De Angelis*2
}

\author{
Address: ${ }^{1}$ Hypertension Unit, Heart Institute (InCor), Medical School, University of Sao Paulo, Sao Paulo-Sao Paulo, Brazil and ${ }^{2}$ Human \\ Movement Laboratory - Sao Judas Tadeu University, Sao Paulo-Sao Paulo, Brazil \\ Email: Bruno Rodrigues - bruno.rodrigues@incor.usp.br; Diego M Figueroa - diego_pumpup@yahoo.com.br; \\ Cristiano T Mostarda - cristiano.mostarda@incor.usp.br; Marcelo V Heeren - marcelovh@pop.com.br; Maria- \\ Cláudia Irigoyen - hipirigoyen@incor.usp.br; Kátia De Angelis* - prof.kangelis@usjt.br \\ * Corresponding author
}

Published: 13 December 2007

Cardiovascular Diabetology 2007, 6:38 doi:10.1186/1475-2840-6-38

This article is available from: http://www.cardiab.com/content/6/1/38

(c) 2007 Rodrigues et al; licensee BioMed Central Ltd.

This is an Open Access article distributed under the terms of the Creative Commons Attribution License (http://creativecommons.org/licenses/by/2.0), which permits unrestricted use, distribution, and reproduction in any medium, provided the original work is properly cited.

\begin{abstract}
Background: The aim of the present study was to investigate the relationship between speed during maximum exercise test (ET) and oxygen consumption $\left(\mathrm{VO}_{2}\right)$ in control and STZ-diabetic rats, in order to provide a useful method to determine exercise capacity and prescription in researches involving STZ-diabetic rats.

Methods: Male Wistar rats were divided into two groups: control $(C G, n=10)$ and diabetic (DG, $\mathrm{n}=8$ ). The animals were submitted to ET on treadmill with simultaneous gas analysis through open respirometry system. $\mathrm{ET}$ and $\mathrm{VO}_{2}$ were assessed 60 days after diabetes induction (STZ, $50 \mathrm{mg} / \mathrm{Kg}$ ).

Results: $\mathrm{VO}_{2}$ maximum was reduced in STZ-diabetic rats $\left(72.5 \pm \mathrm{I} \mathrm{mL} / \mathrm{Kg} / \mathrm{min}^{-1}\right)$ compared to CG rats $\left(8 \mathrm{I} . \mathrm{I} \pm \mathrm{I} \mathrm{mL} / \mathrm{Kg} / \mathrm{min}^{-1}\right)$. There were positive correlations between $\mathrm{ET}$ speed and $\mathrm{VO}_{2}(r=0.87$ for $C G$ and $r=0.8$ for $D G)$, as well as between ET speed and VO, reserve $(r=0.77$ for $C G$ and $r$ $=0.7$ for DG). Positive correlations were also obtained between measured $\mathrm{VO}_{2}$ and $\mathrm{VO}_{2}$ predicted values $(r=0.8 \mathrm{I}$ for $\mathrm{CG}$ and $r=0.75$ for $\mathrm{DG})$ by linear regression equations to $C G\left(\mathrm{VO}_{2}=1.54 *\right.$ ET speed +52.34$)$ and $D G\left(\mathrm{VO}_{2}=1.16 *\right.$ ET speed + 51.99). Moreover, we observed that $60 \%$ of ET speed corresponded to 72 and $75 \%$ of $\mathrm{VO}_{2}$ reserve for $\mathrm{CG}$ and DG, respectively. The maximum ET speed was also correlated with $\mathrm{VO}_{2}$ maximum for both groups (CG: $r=0.7$ and $D G: r=0.7$ ).

Conclusion: These results suggest that: a) $\mathrm{VO}_{2}$ and $\mathrm{VO}_{2}$ reserve can be estimated using linear regression equations obtained from correlations with ET speed for each studied group; b) exercise training can be prescribed based on ET in control and diabetic-STZ rats; c) physical capacity can be determined by ET. Therefore, ET, which involves a relatively simple methodology and low cost, can be used as an indicator of cardio-respiratory capacity in future studies that investigate the physiological effect of acute or chronic exercise in control and STZ-diabetic male rats.
\end{abstract}

\section{Background}

Diabetes is a great public health problem associated with high morbidity and mortality. Frequently, this condition is accompanied by other disorders, such as coronary heart 
disease, hypertension, dyslipidemia and obesity [1]. One consequence of this metabolic condition is the reduced exercise capacity that has been commonly observed in diabetic patients. This reduction is probably dependent on various physiological factors, such as neuromuscular activity, hemodynamics, and respiratory mechanics and oxygen consumption [2].

Maximum oxygen consumption $\left(\mathrm{VO}_{2}\right.$ max $)$ test is highly reproducible, and it is considered a "gold standard" for functional capacity assessment in athletes and sick individuals. This parameter expresses the functional health of the cardiovascular, pulmonary, and skeletal muscle systems [3]. In addition, it provides important prognostic information that is useful for identifying potential candidates for cardiac transplantation $[3,4] . \mathrm{VO}_{2}$ max test also provides objective data, which is helpful in formulating appropriate exercise prescription $[5,6]$. However, sometimes $\mathrm{VO}_{2}$ max measurements have limited use in animal experimentation because of the high cost of the gas analyzer equipment [7] and its time-consuming characteristic.

Maximum and submaximum exercise tests (ET) have been considered safe and well tolerated. This method implies simple measures of functional capacity, and it has been used in clinics, physical qualification programs, and cardiac rehabilitation programs $[8,9]$. The assessment of cardio-respiratory responses to acute and chronic exercise, using different methods (as used in humans), has been a common practice in the investigation of animal models.

In experimental practice, $\mathrm{VO}_{2}$ max measurement is a noninvasive tool that has great value in the study of functional capacity of animals. Therefore, maximum ET, in which animal runs to exhaustion on a graded load treadmill, has been used by our group as an alternative method of evaluation of physical capacity, and it is also used for physical training prescription in health and pathological conditions $[6,10-16]$.

Streptozotocin (STZ)-induced diabetes has been largely used in the study of the role of exercise training in diabetic-induced cardiovascular and autonomic dysfunction $[6,14,16]$. However, the relationship between the speed of ET and $\mathrm{VO}_{2}$, as well as the accuracy of ET in estimating cardio-respiratory capacity remains unclear in STZ-diabetic rats. Therefore, the purpose of the present investigation was to evaluate the relationship between the speeds of ET and both $\mathrm{VO}_{2}$ and $\mathrm{VO}_{2}$ reserve $\left(\mathrm{VO}_{2}\right.$ res) and to validate the equations to predict the $\mathrm{VO}_{2}$ and $\mathrm{VO}_{2}$ res based on speeds of ET in control and STZ-diabetic rats.

\section{Methods}

Experiments were performed on 18 untrained adult male Wistar rats (200-300 g) from the Animal House of the University of Sao Paulo, Sao Paulo, Brazil. Animals received standard laboratory chow and water ad libitum, were housed in collective polycarbonate cages $(n=2 /$ group), and kept in a temperature-controlled room $\left(22^{\circ} \mathrm{C}\right)$ with a 12 -h dark-light cycle (light 07:00-19:00 h). The Medical School of the University of Sao Paulo Institutional Animal Care and Use Committee approved the experimental protocol, and this study was conducted in accordance with the National Institutes of Health (NIH) Guide for the Care and Use of Laboratory Animals. Rats were randomly assigned to 2 experimental groups: control $(\mathrm{CG}, \mathrm{n}=10)$ and diabetic $(\mathrm{DG}, \mathrm{n}=8)$.

\section{Experimental diabetes model}

Experimental diabetes was induced by intravenous injection of $50 \mathrm{mg} / \mathrm{kg}$ of STZ (Sigma Chemical Co., St. Louis, $\mathrm{MO}$ ) dissolved in citrate buffer ( $\mathrm{pH}$ 4.2). Food was withheld from the rats for 6 hours before STZ injection. Control rats received a placebo $(10 \mathrm{mM}$ citrate buffer, $\mathrm{pH}: 4,5)$ after a similar fasting period. 48 hours after STZ injection, blood glucose levels above $200 \mathrm{mg} / \mathrm{dL}$ confirmed the diabetic state.

\section{Measurement of Oxygen Consumption and Maximal Exercise Test}

Sixty days after STZ-induction of diabetes, the animals were placed on a treadmill and enclosed in an airtight metabolic chamber. This chamber was adapted for the determination of $\mathrm{O}_{2}$ uptake $\left(\mathrm{VO}_{2}\right)$ by using an open-circuit method. After 30 minutes of rest on the treadmill, $\mathrm{VO}_{2}$ basal was collected. $\mathrm{VO}_{2}$ was measured by means of expired gas analysis during a ramp protocol of a progressive exercise test, which consists on a treadmill exercise with $3 \mathrm{~m} / \mathrm{min}$ increments every 3 minutes, and finishes when $\mathrm{VO}_{2}$ max is reached. $\mathrm{VO}_{2}$ max was defined as the $\mathrm{VO}_{2}$ after which an increase in work rate was not associated with a further increase $( \pm 5 \%)$ in continuously measured $\mathrm{O}_{2}$ uptake. The metabolic chamber-enclosed treadmill was airtight, except for the front inflow and rear outflow port. Appropriate inspired $\mathrm{PO}_{2}$ was delivered from gas thanks with known concentrations. Inflow was maintained constant at $\sim 6 \mathrm{l} / \mathrm{min}$. Inflowing and outflowing $\mathrm{O}_{2}$ concentrations were measured continuously through an oxygen analyzer (S-3A/I, Ametek, Pittsburgh, PA, USA).

$\mathrm{VO}_{2}$ was calculated using the measured flow through the metabolic chamber (PF), the expired fraction of effluent oxygen $\left(\mathrm{FEO}_{2}\right)$, the fraction of oxygen in room air $\left(\mathrm{FIO}_{2}\right)$, and animals body weight (BW), by the formula previously described by Rolim et al [17]: 


$$
\mathrm{VO}_{2}\left(\mathrm{~mL} / \mathrm{Kg}^{-1} / \mathrm{min}^{-1}\right)=\mathrm{PF}^{*}\left(\mathrm{FIO}_{2}-\mathrm{FEO}_{2}\right) / \mathrm{BW}
$$

The $\mathrm{VO}_{2}$ reserve was calculated by the formula:

$$
\mathrm{VO}_{2} \text { res }\left(\mathrm{mL} / \mathrm{Kg}^{-1} / \mathrm{min}^{-1}\right)=\mathrm{VO}_{2} \text { maximum }-\mathrm{VO}_{2} \text { basal }
$$

\section{Statistical analysis}

The data are reported as mean \pm SEM. A Pearson's product-moment correlation coefficient and univariate was used to evaluate the relationship between: (a) ET and $\mathrm{VO}_{2}$; (b) ET and $\mathrm{VO}_{2}$ res; (c) $\mathrm{VO}_{2}$ measured and $\mathrm{VO}_{2}$ predicted by equation, and (d) $\mathrm{VO}_{2}$ res measured and $\mathrm{VO}_{2}$ res predicted by equation. ANOVA one way, followed by the Student-Newman-Keuls post-hoc test was used to compare groups. Statistical significance was established at $\mathrm{p}<$ 0.05 . Data are reported as means \pm SEM.

\section{Results}

\section{Animal characteristics}

The body weight was lower in DG $(235 \pm 13 \mathrm{~g})$ than in CG $(445 \pm 16 \mathrm{~g})(\mathrm{p}<0.05)$. The diabetic animals developed severe hyperglycemia (DG: $397 \pm 9 \mathrm{mg} / \mathrm{dL}$ ) compared with control animals (CG: $88 \pm 4 \mathrm{mg} / \mathrm{dL})(\mathrm{p}<0.05)$.

\section{Exercise capacity}

Diabetic group presented reduced values of maximum running speed in ET compared with that observed in CG $(19 \pm 1$ vs. $24 \pm 1 \mathrm{~m} / \mathrm{min}, \mathrm{p}<0.01) . \mathrm{VO}_{2} \max (72.5 \pm 1$ vs. $81.1 \pm 1 \mathrm{~mL} / \mathrm{Kg} / \mathrm{min}^{-1}$ in $\left.\mathrm{CG}, \mathrm{p}<0.01\right)$, and $\mathrm{VO}_{2}$ res $\max$ $\left(34 \pm 2\right.$ vs. $51 \pm 1 \mathrm{~mL} / \mathrm{Kg} / \mathrm{min}^{-1}$ in $\left.\mathrm{CG}, \mathrm{p}<0.01\right)$ were also reduced in DG compared with that in $\mathrm{CG}$.

\section{Relationship between ET speed and $\mathrm{VO}_{2}$ or $\mathrm{VO}_{2}$ reserve}

$\mathrm{VO}_{2}$ of both studied groups presented a linear increase during incremental speed protocols. In fact, we observed positive correlations between ET speed and $\mathrm{VO}_{2}$ in $\mathrm{CG}(\mathrm{r}$ $=0.87 ; \mathrm{p}<0.05)$ (Figure $1 \mathrm{~A})$ and DG $(\mathrm{r}=0.81 ; \mathrm{p}<0.05)$ (Figure 1C). Moreover, additional positive correlations were observed between ET speed and $\mathrm{VO}_{2}$ reserve in both CG $(\mathrm{r}=0.77 ; \mathrm{p}<0.05)$ (Figure 1B) and DG (0.70; $\mathrm{p}<$ $0.05)$ (Figure 1D). Linear regression analysis were used to obtain the equations for correlations between ET speed and $\mathrm{VO}_{2}: \mathrm{CG}\left(\mathrm{VO}_{2}=1.54 *\right.$ ET speed +52.34$)$ and DG $\left(\mathrm{VO}_{2}=1.16 *\right.$ ET speed +51.99$)$, and ET speed and $\mathrm{VO}_{2}$ reserve: $\mathrm{CG}\left(\mathrm{VO}_{2}\right.$ res $=1.91^{*}$ ET speed +18.10$)$ and DG $\left(\mathrm{VO}_{2}\right.$ res $=1.17^{*}$ ET speed +14.82$)$.

\section{Control Group}
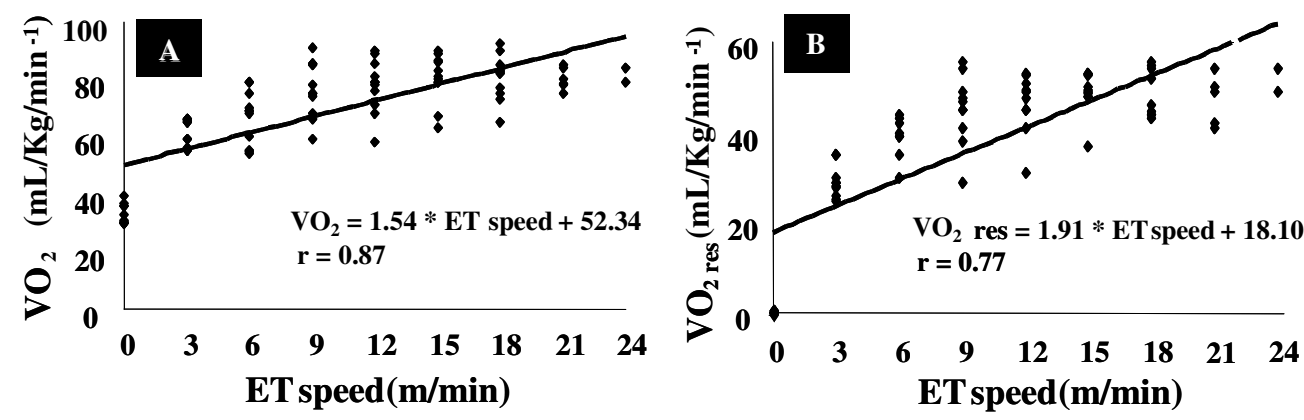

Diabetic Group
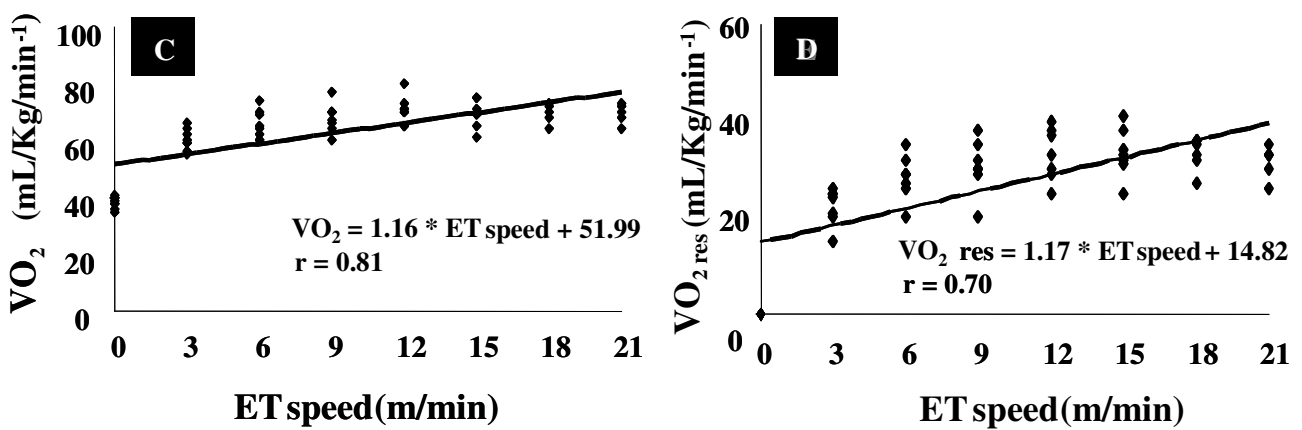

Figure I

Relationships between $\mathrm{VO}_{2}$ and $\mathrm{VO}_{2}$ reserve $\left(\mathrm{VO}_{2}\right.$ res) and exercise test speed (ET speed) in control (CG) and diabetic (DG) groups. 
We also observed a positive correlation between maximum speed of ET and $\mathrm{VO}_{2}$ max for both studied groups: CG $(\mathrm{r}=0.7 ; \mathrm{p}<0.05)$ and DG $(\mathrm{r}=0.7 ; \mathrm{p}<0.05)$. Thus, this data suggests that higher maximal speeds achieved on ET are associated with higher $\mathrm{VO}_{2}$ max values.

\section{Relationship between $\mathrm{VO}_{2}$ and $\mathrm{VO}_{2}$ reserve measured versus predicted}

We tested the correlations between measured $\mathrm{VO}_{2}$ and $\mathrm{VO}_{2}$ predicted by linear regression equation to validate previously proposed predictive equations, and the same was done for $\mathrm{VO}_{2}$ reserve. There were positive correlations between $\mathrm{VO}_{2}$ measured and $\mathrm{VO}_{2}$ predicted $(\mathrm{r}=0.81, \mathrm{p}<$ 0.01 for $\mathrm{CG}$; and $\mathrm{r}=0.75, \mathrm{p}<0.05$ for $\mathrm{DG}$ ), and also between $\mathrm{VO}_{2}$ res measured and $\mathrm{VO}_{2}$ res predicted $(\mathrm{r}=$ $0.83, \mathrm{p}<0.01$ for CG; and $\mathrm{r}=0.75, \mathrm{p}<0.03$ for $\mathrm{DG})$ (Table 1).

\section{Relationship between percentiles of ET and percentiles of $\mathrm{VO}_{2}$ and $\mathrm{VO}_{2}$ reserve}

Exercise prescriptions are commonly based on velocities corresponding to 40,60 , and $85 \%$ of maximum speed of ET. Therefore, we calculated the speed values corresponding to these percentages, considering $24 \pm 1$ and $19 \pm 1 \mathrm{~m} /$ min as $100 \%$ of ET for CG and DG, respectively.

The speed ( $\mathrm{m} / \mathrm{min}$ ) corresponded to each percentile value of ET was applied in the linear regression equations that correlate ET speed and $\mathrm{VO}_{2}$, absolute or reserve, to obtain the estimated $\mathrm{VO}_{2}$, as seen in Table 2 . Finally, the percentiles were calculated for each value of $\mathrm{VO}_{2}$ and $\mathrm{VO}_{2}$ reserve obtained from 40,60, and $85 \%$ of the maximum speed of ET. Corresponding percentiles of $\mathrm{VO}_{2}$ predicted and $\mathrm{VO}_{2}$ reserve predicted based on 40,60 and $85 \%$ of ET are shown in Figure 2.

\section{Discussion}

The worldwide epidemic of diabetes that have emerged with the dawning of the 21st century has shown to be a major public heath problem, having struck developed countries as well as those still developing [1]. The diabetes induced by streptozotocin has been a largely used in animal models to study diabetic-induced cardiovascular and autonomic dysfunction [5,18-20].

It is well known that laboratory animals are constantly used in exercise physiology and cardiovascular rehabilitation research. However, the measurement of oxygen consumption in small animals is, many times, a limitation factor for research in this area, not only because of the high costs of gas analyses systems $[7,21]$, but also because of two other important factors. First, the $\mathrm{VO}_{2}$ measurement must be carried out in a separate place from the rest of the laboratory to prevent alterations in the concentration of gases around the environment during data acquisition, and second, it is time-consuming because $\mathrm{VO}_{2}$ stabilization can take some time in rats. Moreover, the closed environment of the respiratory chamber may provoke one more stress situation for the experimental animal.

Although various instruments for human $\mathrm{VO}_{2}$ and $\mathrm{VO}_{2}$ reserve acquisition exist, to our knowledge, the respiratory chamber is the only one permitting continuous direct monitoring of $\mathrm{VO}_{2}$ in laboratory animals [17].

Studies of our laboratory have been conducted to investigate the benefits of exercise training in STZ-diabetic rats $[6,14,16]$ and others pathological conditions $[10,13,15]$, using the exercise training prescription based on maximal exercise test. In the present study, we have demonstrated that STZ-diabetes reduces $\mathrm{VO}_{2}$ max, $\mathrm{VO}_{2}$ res max and maximum running speed on ET. Furthermore, we also obtained significant correlations between $\mathrm{VO}_{2}$ and ET

Table I: Relationships between measured $\mathrm{VO}_{2}$ and $\mathrm{VO}_{2}$ reserve with predicted $\mathrm{VO}_{2}$ and $\mathrm{VO}_{2}$ reserve.

\begin{tabular}{|c|c|c|c|c|c|c|}
\hline & Variables & Mean \pm SEM $(\mathrm{ml} / \mathrm{Kg} / \mathrm{min})$ & r Value & $\mathbf{r}^{2}$ Value & $\begin{array}{c}p \text { Value } \\
\text { (Pearson correlation) }\end{array}$ & SEE \\
\hline \multirow[t]{2}{*}{ CG } & $\begin{array}{l}\mathrm{VO}_{2} \text { max measured } \\
\mathrm{VO}_{2} \text { max predicted }\end{array}$ & $\begin{array}{l}81.1 \pm 1 \\
89.5 \pm 4\end{array}$ & 0.81 & 0.66 & 0.0077 & 9.7 \\
\hline & $\begin{array}{l}\mathrm{VO}_{2} \text { res max measured } \\
\mathrm{VO}_{2} \text { res max predicted }\end{array}$ & $\begin{array}{l}51.2 \pm 1 \\
56.0 \pm 5\end{array}$ & 0.83 & 0.69 & 0.0053 & 9.4 \\
\hline \multirow[t]{2}{*}{ DG } & $\begin{array}{l}\mathrm{VO}_{2} \text { max measured } \\
\mathrm{VO}_{2} \text { max predicted }\end{array}$ & $\begin{array}{l}72.5 \pm 1^{*} \\
74.6 \pm 3^{*}\end{array}$ & 0.75 & 0.56 & 0.0314 & 7.7 \\
\hline & $\begin{array}{l}\mathrm{VO}_{2} \text { res max measured } \\
\mathrm{VO}_{2} \text { res max predicted }\end{array}$ & $\begin{array}{l}34.4 \pm 2^{*} \\
32.2 \pm 3^{*}\end{array}$ & 0.75 & 0.57 & 0.0289 & 7.7 \\
\hline
\end{tabular}

Data are reported as mean \pm SEM. $r$ and $r^{2}$ values, standard error estimate $-\mathrm{SEE}$ and $p$ values of Pearson correlation are presented; VO $\mathrm{O}_{2}$ max: maximal oxygen consumption; $\mathrm{VO}_{2}$ res max: reserve maximal oxygen consumption; CG: control group; DG: diabetic group; ${ }^{*} \mathrm{p}<0.05$ vs. CG (oneway ANOVA). 
Table 2: Relationship between percentiles of exercise test and percentiles of $\mathrm{VO}_{2}$ and $\mathrm{VO}_{2}$ reserve.

\begin{tabular}{|c|c|c|c|c|c|c|}
\hline & \%ET & $\begin{array}{c}\text { ET speed predicted } \\
(\mathrm{m} / \mathrm{min})\end{array}$ & $\mathrm{VO}_{2}$ predicted $\left(\mathrm{ml} / \mathrm{Kg} / \mathrm{min}^{-1}\right)$ & $\mathrm{VO}_{2}$ predicted & $\begin{array}{c}\mathrm{VO}_{2} \text { reserve predicted } \\
\left(\mathrm{ml} / \mathrm{Kg} / \mathrm{min}^{-1}\right)\end{array}$ & $\begin{array}{c}\% \mathrm{VO}_{2} \text { predicted } \\
\text { reserve }\end{array}$ \\
\hline \multirow[t]{4}{*}{ CG } & 40 & 10 & 67 & 75 & 34 & 59 \\
\hline & 60 & 14 & 75 & 83 & 41 & 72 \\
\hline & 85 & 20 & 84 & 94 & 51 & 89 \\
\hline & 100 & 24 & 89 & 100 & 56 & 100 \\
\hline \multirow[t]{4}{*}{ DG } & 40 & 8 & 61 & 82 & 23 & 63 \\
\hline & 60 & 12 & 66 & 88 & 27 & 75 \\
\hline & 85 & 17 & 71 & 95 & 33 & 91 \\
\hline & 100 & 19 & 75 & 100 & 36 & 100 \\
\hline
\end{tabular}

Values calculated by linear regression equation (Pearson's correlation coefficient and univariate) from percentiles $(40,60,85$ and $100 \%)$ of exercise test. ET: exercise test; $\mathrm{VO}_{2}$ : oxygen consumption; $\mathrm{CG}$ : control group; DG: diabetic group.

speed, $\mathrm{VO}_{2}$ reserve and $\mathrm{ET}$ speed and $\mathrm{VO}_{2}$ max and maximum ET speed in control and STZ-diabetic rats.

Accurate monitoring of $\mathrm{VO}_{2}$ consumption healthy or sick subjects is of great interest to medical research [22,23]. Researches have been wide for indirect forms of estimating $\mathrm{VO}_{2} \max [7,24,25]$. In 1954, Astrand \& Ryhming [24] published a nomogram to predict $\mathrm{VO}_{2}$ max from submaximal pulse rates (120 to $170 \mathrm{bpm}$ ). Some years later, this nomogram was modified, and it is still being used today
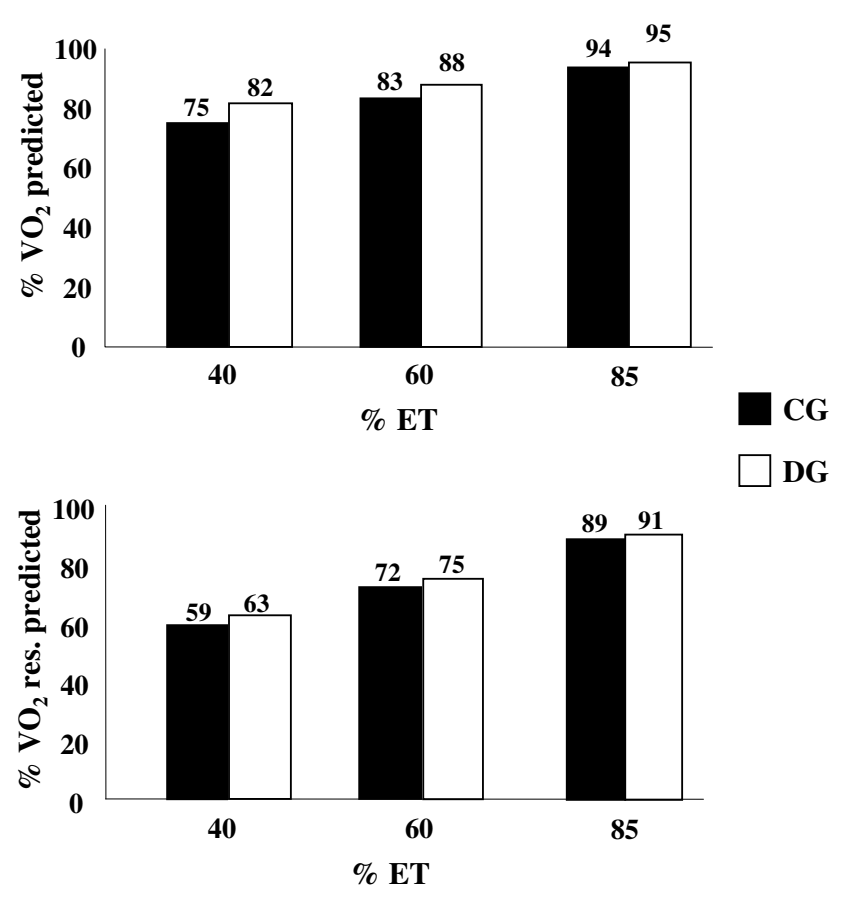

\section{Figure 2}

Corresponding percentiles of $\mathrm{VO}_{2}$ predicted and $\mathrm{VO}_{2}$ reserve predicted $\left(\mathrm{VO}_{2}\right.$ res. predicted) based on 40,60 and $85 \%$ of exercise test (\%ET) in control (CG) and diabetic (DG) groups.
[26]. Balke \& Ware [27], in 1959, developed a new protocol, and established a formula to calculate $\mathrm{VO}_{2}$ based on the speed and on treadmill slope [28]. In addition, recently, Maldonado-Martin et al. [29] demonstrated a good correlation between $\mathrm{VO}_{2}$ peak and the 6-minute walking test (6-MWT) in heart failure patients. However, these authors also concluded that when $\mathrm{VO}_{2}$ (peak) is predicted from equations using 6-MWT, the result is a substantial variability. Consequently, it should not be used in older HF patients, in which an accurate determination of functional capacity is essential. Currently, $\mathrm{VO}_{2} \max$, for both health men and women, can be estimated according to the formulas adopted by the American College of Sports Medicine [30].

The maximum $\mathrm{VO}_{2}$ values obtained in the present work are in accordance with previous findings for normal adult rats [31]. Likewise, the maximum speed values obtained in the exercise test are considered adequate values for rats and mice $[7,13,15,26]$. The reduction in $\mathrm{VO}_{2} \max$ observed in diabetic rats can be due to many factors, such as cardiac output limitations $[5,6]$, reduced peripheral blood flow [32] and problems in skeletal muscle metabolism [33].

The results of the present study provide values of $\mathrm{VO}_{2}$ for adult Wistar male rats at different treadmill speeds. In the range of treadmill speeds, 3 to $24 \mathrm{~m} / \mathrm{min}$ for CG and 3 to $19 \mathrm{~m} / \mathrm{min}$ for $\mathrm{DG}, \mathrm{VO}_{2}$ increased progressively as a function of running speed, and it could be expressed by simple linear equations obtained by linear regression $\left(\mathrm{VO}_{2}=1.54\right.$ * ET speed + 52.34, for CG; and $\mathrm{VO}_{2}=1.16 *$ ET speed + 51.99, for DG). This equation allows $\mathrm{VO}_{2}$ estimation for one definitive workload, and it also gives the $\mathrm{VO}_{2} \max$ from the maximum ET speed.

The increment in $\mathrm{VO}_{2}$ as a function of speed (Figure 1) was described in previous studies [34,35], and other predicted forms were proposed for Wistar-Kyoto and Sponta- 
neously Hypertensive Rats [36]. However, our study has shown that STZ-diabetic rats present different slopes of $\mathrm{VO}_{2}$ in response to speed increment when compared to control rats. In fact, available data suggests that each experimental rat model needs a specific equation to predict the $\mathrm{VO}_{2}$ and $\mathrm{VO}_{2}$ reserve.

In this study, we tested the approximation between measured $\mathrm{VO}_{2}$ and $\mathrm{VO}_{2}$ reserve with $\mathrm{VO}_{2}$ and $\mathrm{VO}_{2}$ reserve predicted by linear regression equations in study groups. Significant correlations were observed between measured $\mathrm{VO}_{2}$ and $\mathrm{VO}_{2}$ reserve with predicted $\mathrm{VO}_{2}$ and $\mathrm{VO}_{2}$ reserve variables for CG $(r=0.81$ and $r=0.83 ; \mathrm{p}<0.003)$ and $D G$ $(r=0.75$ and $r=0.75 ; p<0.005)$, respectively. Thus, our study has showed that these equations, which are used to predict $\mathrm{VO}_{2}$ and $\mathrm{VO}_{2}$ reserve from ET, are valid for control and STZ-diabetic rats.

In exercise physiology, it is common and appropriate to characterize work intensity as percentage of $\mathrm{VO}_{2}$ max. In this study, it was observed that $60 \%$ of the maximum ET speed (CG: $14 \mathrm{~m} / \mathrm{min}$ and DG: $12 \mathrm{~m} / \mathrm{min}$ ) corresponded to $83 \%$ of $\mathrm{VO}_{2}$ max and $72 \%$ of $\mathrm{VO}_{2}$ reserve in CG and $88 \%$ of $\mathrm{VO}_{2}$ max and $75 \%$ of $\mathrm{VO}_{2}$ reserve in DG. In animal models, a correlation between ET speed and $\mathrm{VO}_{2}$ was also established for adult and old C57BL/6J mice. In this study, the authors found that the speed of $12 \mathrm{~m} / \mathrm{min}(\sim 50 \%$ of the maximum ET speed) produced a $\mathrm{VO}_{2}$ equivalent to $76 \%$ and $89 \%$ of the $\mathrm{VO}_{2}$ max in adult and old mice, respectively [7]. Furthermore, Wisloff et al. [31] have demonstrated a linear relationship between $\mathrm{VO}_{2}$ and $\mathrm{HR}$ in sedentary and trained rats according to the increment of ET speed. Nevertheless, these authors emphasized that the maximum $\mathrm{HR}$ is not reached along with $\mathrm{VO}_{2}$ max. Instead, it is reached in intensities above $\mathrm{VO}_{2}$ max. Moreover, this study indicates that values of $90 \%$ of the maximum HR correspond to $\sim 80 \%$ of the $\mathrm{VO}_{2}$ max.

It is important to highlight the positive correlations observed in the present study between maximum ET speed and $\mathrm{VO}_{2}$ max in CG $(\mathrm{r}=0.7, \mathrm{p}<0.05)$ and DG $(\mathrm{r}=$ $0.7, \mathrm{p}<0.05)$. These correlations demonstrate that rats with higher ET performance presented higher $\mathrm{VO}_{2} \max$. As a result, this finding suggests that a simple ET is capable of detecting differences in the cardio-respiratory capacity of control and diabetic-STZ rats, and it also suggests that the improvement in cardio-respiratory performance $\left(\mathrm{VO}_{2} \mathrm{max}\right)$ after a period of physical training could be detected by maximum ET. In this aspect, it is important to emphasize that Noakes et al. [37] previously demonstrated that the highest speed reached in maximum ET is a better predictor of performance in laboratory tests when compared to $\% \mathrm{VO}_{2}$ max, $\mathrm{VO}_{2}$ max or racing speed at an extreme lactate threshold among marathon athletes. In our group, we have used ET as an indicator of improve- ment of exercise capacity after exercise training in diabetic, hypertensive ovariectomized rats and in normal mice [12$16]$.

\section{Conclusion}

The results of the present study demonstrated that $\mathrm{VO}_{2}$ can be estimated from the results of ET in control and STZdiabetic rats. This estimate can be assessed by obtaining equation by linear regression between $\mathrm{VO}_{2}$ and ET. The correlation between ET speed and $\mathrm{VO}_{2}$ showed that physical training prescription based on ET is adequate for control and diabetic animals. Furthermore, our data indicates that ET can detect differences in aerobic performance, as the maximum speed achieved in the ET was correlated with the maximum $\mathrm{VO}_{2}$ in these evaluated experimental models.

Therefore, we concluded that maximal exercise test can be used as an indicator of cardio-respiratory capacity, and it can be useful in further studies that investigate physiological effect of acute or chronic exercise on control and STZdiabetic male rats.

\section{Abbreviations \\ $\mathrm{VO}_{2}$ : oxygen consumption \\ $\mathrm{VO}_{2}$ max: maximum oxygen consumption \\ $\mathrm{VO}_{2}$ res: oxygen consumption of reserve}

ET: exercise test

STZ: streptozotocin

CG: control group

DG: diabetic group

\section{Competing interests}

The author(s) declare that they have no competing interests.

\section{Authors' contributions}

The authors BR, DMF, CTM and MVH carried out the exercise test, maximal oxygen consumption data acquisition, performed the statistical analyses and discussion of results. BR, MCI and KDA participated in the study design and alignment, discussion of results, statistical analyses, and drafted the manuscript. MCI and KDA conceived the study, and participated in its design and coordination. All authors read and approved the final manuscript.

\section{Acknowledgements}

This study was supported by Coordenação de Aperfeiçoamento de Pessoal de Nível Superior (CAPES), Fundação de Amparo a Pesquisa do Estado de São Paulo (FAPESP 05/60829-2, 06/53739-0), Conselho Nacional de 
Pesquisa (CNPq 477226/2004-3) and the Zerbini Foundation. We thank Cláudia Borim and Natale Rolim for their helpful input in data acquisition, statistical analysis and discussion of results.

\section{References}

I. Wang J, Armour T, Geiss LS, Engelgau MM: Obesity and diabetes: dual epidemics on the rise. Curr Opin Endocrinol Diabetes 2005 I 2:174-180

2. Komatsu WR, Gabbay MA, Castro ML, Saraiva GL, Chacra AR, de Barros Neto TL, Dib AS: Aerobic exercise capacity in normal adolescents and those with type I diabetes mellitus. Pediatr Diabetes 2005, 3:145-149.

3. Myers J, Gullestad L, Vagelos R, Do D, Bellin D, Ross H, Fowler MB: Clinical hemodynamic and cardiopulmonary exercise test determinants of survival in patients referred for evaluation of heart failure. Ann Intern Med 1998, I 29:286-293.

4. Armstrong LE, Brubaker PH, Otto RM: ACSM's Guidelines for Exercise Testing and Prescription. In In American College of Sports Medicine 7th edition. Baltimore: Lippincott Williams \& Wilkins; 2005:66-99.

5. Wichi R, Malfitano C, Rosa K, De Souza SB, Salemi V, Mostarda C, De Angelis K, Irigoyen MC: Noninvasive and invasive evaluation of cardiac dysfunction in experimental diabetes in rodents. Cardiovasc Diabetol 2007, 26:6-14.

6. De Angelis KL, Oliveira AR, Dall'Ago P, Peixoto LR, Gadonski G, Lacchini S, Fernandes TG, Irigoyen MC: Effects of exercise training on autonomic and myocardial dysfunction in streptozotocindiabetic rats. Braz J Med Biol Res 2000, 6:635-64I.

7. Schefer $\mathrm{V}$, Talan MI: Oxygen consumption in adult and aged C57BL/6J mice during acute treadmill exercise of different intensity. Exp Gerontol 1996, 3:387-392.

8. Bittner V, Weiner DH, Yusuf S, Rogers WJ, McIntyre KM, Bangdiwala SI, Kronenberg MW, Kostis JB, Kohn RM, Guillotte M, Greemberg B, Woods PA, Bourassa MG: Prediction of mortality and morbidity with a 6-minute walk test in patients with left ventricular dysfunction. SOLVD investigators. JAMA I993, 270: I702-1707.

9. Cahalin LP, Mathier MA, Semigran MJ, William G, Disalvo TG: The six-minute walk test predictors peak oxygen uptake and survival in patients with advanced heart failure. Chest 1996, I 1 0:325-332.

10. Bertagnolli M, Campo C, Schenkel PC, de Oliveira VL, De Angelis K, Bello-Klein A, Rigatto K, Irigoyen MC: Baroreflex sensitivity improvement is associated with decreased oxidative stress in trained spontaneously hypertensive rat. Hypertension 2006, 1 2:2437-43.

II. De Angelis KL, Oliveira AR, Werner A, Bock P, Belló-Klein A, Fernandes TG, Belló AA, Irigoyen MC: Exercise training in aging: hemodynamic, metabolic, and oxidative stress evaluations. Hypertension 1997, 30(3 Pt 2):767-7I.

12. De Angelis Lobo d'Avila K, Gadonski G, Fang J, Dall'Ago P, Albuquerque VL, Peixoto LR, Fernandes TG, Irigoyen MC: Exercise reverses peripheral insulin resistance in trained L-NAME hypertensive rats. Hypertension 1999, 34(2):768-772.

13. De Angelis K, Wichi RB, Jesus WR, Moreira ED, Morris M, Krieger EM, Irigoyen MC: Exercise training changes autonomic cardiovascular balance in mice. J Appl Physiol 2004, 96(6):2 174-78.

14. Harthmann AD, De Angelis K, Costa LP, Senador D, Schaan BD, Krieger EM, Irigoyen MC: Exercise training improves arterial baro- and chemoreflex in control and diabetic rats. Auton Neurosci 2007, 133(2): I I5-20

15. Irigoyen MC, Paulini J, Flores LJ, Flues K, Bertagnolli M, Moreira ED, Consolim-Colombo F, Bello-Klein A, De Angelis K: Exercise training improves baroreflex sensitivity associated with oxidative stress reduction in ovariectomized rats. Hypertension 2005, 46(2): $1-6$.

16. Souza SB, Flues K, Paulini J, Mostarda C, Rodrigues B, Souza LE, Irigoyen MC, De Angelis K: Role of Exercise Training in Cardiovascular Autonomic Dysfunction and Mortality in Diabetic Ovariectomized Rats. Hypertension :786-791. 2007 Jul 30

17. Rolim NP, Mattos KC, Brum PC, Baldo MV, Middlekauff HR, Negrao $C E$ : The decreased oxygen uptake during progressive exercise inischemia-induced heart failure is due to reduced cardiac output rate. Braz J Med Biol Res 2006, 39(2):297-304.
18. De Angelis K, Schann BD, Dall'Ago P, Maeda CY, Wichi R, Irigoyen MC: Cardiovascular control in experimental diabetes. Braz $J$ Med Biol Res 2002, 35(9): |09|-I 100.

19. Schaan BD, Dall'Ago P, Maeda CY, Ferlin E, Fernandes TG, Schmid H, Irigoyen MC: Relationship between cardiovascular dysfunction and hyperglycemia in streptozotocin-induced diabetes in rats. Braz J Med Biol Res 2004, 37: 1895- 1902.

20. Monckton G, Pehowich E: Autonomic neuropathy in the streptozotocin diabetic rat. Can J Neurol Sci 1980, 7: I35-I 42.

21. Rostagno C, Olivo G, Comeglio M, Boddi V, Banchelli M, Galanti G, Gensini GF: Prognostic value of 6-minute walk corridor test in patients with mild to moderate heart failure: comparison with other methods of functional evaluation. Eur J Heart Fail 2003, 5:247-252.

22. Arena R, Myers J, Aslam SS, Varughese EB, Peberdy MA: Influence of subject effort on the prognostic value of peak VO2 and the VE/VCO2 slope in patients with heart failure. I Cardiopulm Rehabil 2004, 24(5):317-20.

23. Anker SD, Coats AJ: Peak $\mathrm{VO}_{2}$ for prognosis in heart failure? Am Coll Cardiol 1999, 33(2):591-2.

24. Astrand PO, Ryhming A: Nomogram for calculation of aerobic capacity (physical fitness) from pulse rate during submaximal work. J Appl Physiol 1954, 7:218

25. Rerup CC: Drugs producing diabetes through damage of the insulin secreting cells. Pharmacol Ver 1970, 22(4):485-5।8.

26. Astrand I: Aerobic work capacity in men and women with special reference to age. Acta Physiol Scand Suppl 1960, 49( 169): I-92.

27. Balke B, Ware RW: An experimental study of physical fitness of Air Force personnel. U S Armed Forces Med J 1959, I0(6):875-88

28. Vivacqua R, Hespanha R: Introduction, History, Perspectives. In Ergometry Rehabilitation in Cardiology Volume 2. Rio de Janeiro: Med; 1992:1-6.

29. Maldonado-Martin S, Brubaker PH, Kamisky LA, Moore JB, Stewart KP, Kitzman DW: The relationship of a 6-min walk to VO2 (peak) and VT in older heart failure patients. Med Sci Sports Exerc 2006, 38(6): 1047-53.

30. Armstrong LE, Brubaker PH, Otto RM: ACSM's Guidelines for Exercise Testing and Prescription. In In American College ofSports Medicine 2nd edition. Baltimore:LippincottWilliams \& Wilkins; 1999:237-50.

31. Wisløff U, Helgerud J, Johan Kemi O, Ellingsen O: Intensity-controlled treadmill running in rats: $\mathrm{VO}_{2}$ max andcardiac hypertrophy. Am J Physiol (Heart Circ Physiol) 200I, 280:I30I-I3I0.

32. Kindig CA, Sexton WL, Fedde MR, Poole DC: Skeletal muscle microcirculatory structure and hemodynamics in diabetes. Respir Physiol 1998, I I I(2): I63-75.

33. De Angelis KL, Cestari IA, Barp J, Dall'Ago P, Fernandes TG, de Bittencourt PI, Bello-Klein A, Bello AA, Llesuy S, Irigoyen MC: Oxidative stress in the latissimus dorsi muscle of diabetic rats. Braz J Med Biol Res 2000, 33( I I): 1363-8.

34. Gleeson TT, Baldwin KM: Cardiovascular Response to Treadmill Exercise in Untrained Rats. J Appl Physiol Respirat Environ Exercise Physiol 1981, 50(6): I206-121I.

35. Musch TI, Bruno A, Bradford GE, Vayonis A, Moore RL: Measurements of metabolic rate in rats: a comparison of techniques. J Appl Physiol 1988, 65(2):964-70.

36. Bedford TG, Tipton CM, Wilson NC, Oppliger RA, Gisolfi CV: Maximum oxygen consumption of rats and its changes with various experimental procedures. J Appl Physiol 1979, 47(6): $1278-83$

37. Noakes TD, Myburgh $\mathrm{KH}$, Schall R: Peak treadmill running velocity during the $\mathrm{O}_{2}$ max test predicts running performance. $]$ Sports Sci 1990, 8(I):35-45. 